\title{
Marine Quarantine and Illegal Fishing Boat Sinking in Indonesian Water
}

\author{
$1^{\text {st }}$ Chomariyah \\ Faculty of Law \\ Universitas Hang Tuah Surabaya \\ Surabaya, Indonesia \\ chomariah@hangtuah.ac.id
}

\begin{abstract}
Marine quarantine which is known so far is activities usually done to the boat and the passengers who are infected by diseases. But marine quarantine in this research is activities included into Standard Operational Procedure (SOP) to prevention activity for the foreign boat pollution of Illegal Fishing caught in Indonesian waters then the sinking action will increase. SOP about illegal fishing boat sinking has been regulated in Regulation of Marine and Fisheries Minister No. 37/PERMEN-KP/2017 about Standard Operational Procedure for Law Enforcement of Task Force for Illegal Fishing Eradication. The research method used is normative juridical research, that is documenting the boat sinking is analyzed suitable with the existing regulations and combined with the legal event occurs and interview with the relevant officials to complete the existing document. The results showed the marine quarantine needed as one of procedures of prevention which should be done before the illegal fishing boat sinking done. Marine quarantine with several procedures, that is cleaning the boat, sinking area selection and the sinking procedure to keep the environment conserved and with efficient cost.
\end{abstract}

Keywords-Illegal fishing, marine quarantine, standard operational procedure.

\section{INTRODUCTION}

Capture fisheries sector has very great contribution in Indonesia. Production potential of capture fisheries production in Indonesia increase from previously 5,8 million ton $\mathrm{s}$ to 7,9 million tons. The increase of 2,1 million tons because the amount of sustainable potential increase [1]. But if not control toward the fish potentials then the potentials will decrease because of Illegal Fishing practice. Several practice of illegal fishing such as, the fishing boat fleet intentionally enter into exclusive economic zone of certain country without permission and catch excessive fishes.

With the illegal fishing in the Indonesian waters make the law enforcers try to give sanction for the doers. Based on article 69 paragraph (1) Law No 45Year 2009 juncto Law No 31 Year 2004 about Fisheries, and Article 69 paragraph (4), that is the special action in the form of burning and or boat sinking based on sufficient proof. According to the report of Directorate of Violation Handling year 2016 [2]. Total of illegal fishing boat sunk by government since October 2014 of 2017 boats. Vietnam, Thailand, Papua New Guinea, Philippine, Taiwan, China and Malaysia, with the sinking location of Riau Island, Bitung of North Sulawesi, Benoa Bali, Tarakan of North Kalimantan, Pangandaran of West Java, Morotai of North Maluku and Sorong of West Papua. By looking at the sinking location distribution, no specific place for the boat sinking.
On March 13, 2016 illegal fishing boat of MV Viking with Nigerian flag was sunk at Pangandaran beach of West Java by Ministry of Maritime and Fisheries. But on June 182016 marine pollution caused by diesel and oil from the boat, so polluted the TanjungBatu Mandi area of Natural Preservation of Pangandaran, West Java [3]. The pollution occurrence produce polemic in the law enforcers circle and DPR ( Commission VI) it needs to reinvestigate about the illegal fishing boat sinking. Wahli assessed the explosion as the dereliction. Based on the explanation above then the researcher interested to do research about legislation of illegal fishing boat sinking through quarantine method as effort to prevent the marine pollution in Indonesia.

Table 1. Amount of countries and boats arrested in Indonesian waters

\begin{tabular}{|c|c|c|}
\hline No & Countries & Boat amounts \\
\hline 1. & Vietnam & 63 \\
\hline 2. & Philippine & 43 \\
\hline 3. & Malaysia & 30 \\
\hline 4. & Thailand & 21 \\
\hline 5. & Indonesia & 14 \\
\hline 6. & Papua New Guinea & 2 \\
\hline 7. & RRC & 1 \\
\hline 8. & Belize & 1 \\
\hline 9. & Nigeria & 1 \\
\hline
\end{tabular}

Problem of illegal fishing boat in hundreds produce special problems related to the sinking procedures. Problem of standard operational procedure which is not optimal will produce problems with the neighborhood states which are inflicted by financial loss. Based on the background above then the problem formulation in the research as follows: what is the impact of illegal fishing sinking in Indonesia? What procedures that are used in the illegal fishing boat to avoid pollution in the Indonesian waters?

\section{RESEARCH METHODS}

Legal materials which were analyzed consist of primary and secondary materials. Primary legal materials used taken from the legislation. To solve problems and answer the questions stated, then in the research is used normatiove legal investigation and deductive method by using statute approach. Normative investigation is determination of main problems appropriately then taken the legal issues or the supporting component. Deductive method is based on the investigation to the general principles used to explain the special events or theoretical explanation with concrete nature. Legal materials analyzed consist of primary materials and secondary materials. 
Primary materials used taken from legislation. To solve the problems and answer the questions the research used normative and deductive method by using statute approach. Normative investigation is determination of main problems appropriately then taken the related issues and supporting component. Deductive method is based on the investigation to the general principles used to explain the special events or theoretical explanation with concrete nature. The research investigated the marine quarantine and illegal fishing boat sinking in Indonesian waters, the problems will be investigated from legal dogmatic level, legal theories, and legal philosophy, and analyzed suitable with the character of each science.

Legal dogmatic and legal theories by using normative method, legal philosophies although no have special method, because the philosophy field not reached by science, but used to do reflection. Function of legal dogmatic used to give valuation toward legislation which is related with the implementation of Standard Operational Procedure that will enter the marine quarantine method as the part of boat sinking process. Legal philosophy be used to reflect basic law, that is the basic justification the need of sinking sanction implementation without court decision.

Legal materials, either primary or secondary which are inventoried and identified will be grouped systematically. From the international, regional and national legal instruments. The steps were expected able to facilitate discussion analysis suitable with the legal problems identified in detail.

Primary and secondary legal materials that will be analyzed as follows:

a. At the legal dogmatic level will be done description, systematization, and analysis toward national regulation which is related with the illegal fishing boat sinking, the sinking process and institutions that has authority to determine the sanction.

b. At the legal theory level, it will be analyzed the legal theories which are related to the Indonesian authorities as the sovereign country that has sovereignty to implement the sinking sanction without intervention of others country and will be analyzed the needed steps in the sanction implementation so no produce conflict with the neighborhood countries.

c. At the philosophical level, will be analyzed about marine quarantine method that include the boat cleaning not only the crew but also the contents that able to produce pollution for environment and develop effort to implement legal enforcement procedurally suitable with national and international law.

\section{RESULTS AND DISCUSSION}

Previous research

Research about sinking of illegal fishing boat not something new but the research which focus to the sinking procedure is the new one, previous research has been done by researchers as follows:

1. M. RizqiIsnurhadi[4] studied about "Illegal, Unreported, Unregulated Fishing (IUUF) in Indonesian Waters in Era of Joko Widodo administration", the results showed that many IUU Fishing activities in Indonesian waters are threat for fishery industry in Indonesia. The researcher give solution in the form of speech act as securitizing move through speech collection or governmental publication especially the Marine and Fishery Ministry (KKP) to be analyzed and analyzing the securitizing move effectiveness in solving the IUU Fishing problems.

2. AyuEfritadewi and Wan Jefrizal,[5], investigated about "Illegal fishing boat sinking in Indonesia area in the perspective of international law" with results the sanction giving in the form of sinking is effort of the state in eradicating the illegal fishing and giving deterrent effect to the doers. The sinking impact bring pros and cons but the positive impact for Indonesian government able to stop the illegal fishing activities and save the Indonesian waters.

3. Yusuf Istanto,[6], studied about "illegal fishing boat sinking as effort to enforce the fishery law in Indonesia (Study of Decision No 4/PID.SUSPRK/3014/PN-TPG District Court of Tanjung Pinang)". The results, the firm action of illegal fishing boat sinking based on Article 69 paragraph (1) and paragraph (4) fishery law, aimed at showing the firmness and authority of Indonesian government tin protecting the sovereignty of Indonesia and the natural resources. The action also producing deterrent effect at the illegal fishing doers.

4. Tang Jiahua[7], studied about " the development of China's Marine Security Strategy. The research discusses of the maritime security was expanded and steered, from traditional military security to nontraditional security. And also, the cooperation in marine economy, management of transnational crimes was increased steadily.

5. Qunsheng Chen[8], studied about “ analysis of current status and cuses of maritime acaccidents. The result was maritime accidents can be reduced by inspection and control of the ship, ship operating management and navigation and improve the quality of personnel. And also to prevent sea pollution, ensure safety of life at sea and enhance the overall safety of the shipping. 
6. Compared to the previous researches done by previous the researchers, there are different thing with the research such as:

a. The research used special subject, that is marine quarantine entered into standard operational procedure of foreign boat sinking;

b. The research used normative method that so far misunderstood by researcher in investigating policy, normative research different with policy research of law understood as normative symptoms which is autonomous and separated from the social symptoms;

c. Object or the research objective is the determination of standard operational procedures through procedural steps in foreign boat sinking that do illegal fishing in Indonesian waters suitable with the Marine and Fishery Minister Regulation No. 37/PERMEN-KP/2017 [11] about standard operational procedure of law enforcement of illegal fishing taskforce and the other law materials;

d. Normative research method as tool to find truth, that is in the form of truth aimed at "order of logic". At the "order of logic" the truth value of statement should base on the logic use that is harmonious and regular, way of thinking that can be followed the steps because follow the principle.

In the research it is expected will produce different analysis from the legal analysis and can solve emerging problems in the illegal fishing foreign boat from the prevention of environmental pollution and the procedural certainty of the sinking.

Illegal fishing problems is problem that should be solved, because of that the Indonesian government in this case KKP try to rebuild the marine and fishery sector in Indonesia based on the principle of sovereign, sustainability, and prosperity. The three principles are developmental pillars of marine and fishery in Indonesia which is related one another and cannot stand alone.

Sovereignty pillar and state sovereignty should be enforced so Indonesian state should be enforced so Indonesian nation can free to determine their fate in sea, without other nation intervention, for the national interest. Protect the sovereignty not only to protect the border of the Unitary State of The Republic of Indonesia, but also protect the resources in it so can be used maximally for the prosperity of the Indonesian people, suitable with the goals in the opening of Constitution 1945 .

The sovereignty foundation is sovereign theory from JearBodin that defines the sovereignty as the highest power in a state, has single character, original, immortal and not divided. State sovereignty into inside is the highest power to regulate state suitable with the function, while sovereignty into outside is the highest power to make relationship with other country and defend the are from threat from outside.

Article 33 paragraph (3) UUD 1945 states the earth, water and natural resources contained in it mastered by state and used for the people prosperity. State mastery right means the government has authority to formulate policy, make regulation, manage, and control the marine and fishery resources in Indonesia.

Illegal fishing eradication step is main priority to enforce the Indonesian sovereignty. Beside those mentioned above, illegal fishing also has potential to produce conflict among state as claim for marine territory and the use right for the natural resources in it. Because of that, effort to eradicate illegal fishing based on sovereignty pillar, is important in oversee the vision embodiment of Indonesia as the maritime axis of the world [9].

Sustainability pillar is important to ensure the marine wealth of Indonesia not used up only for one generation only. Suitable with the vision "Sea is the State Future", sea must able to support national development and improve the life quality of Indonesian nation in today and in the future. So the sustainable use approach should be done to avoid "tragedy of freedom in a commons" as the threat for the resources sustainability. Tragedy of freedom in a commons according to Garrett Hardin (1968) is a situation where the no regulation condition cause individuals exploit the natural resources unlimitedly for their own interest. Fish resources should be "sustainable and viable" so Indonesia not only known in the world as the fish supplier, but also as state that protect the marine and fishery resources.

Sustainable development paradigm has been stated in Constitution 1945, that mandates the economic is implemented based on sustainability and environmentally friendly. So far the conventional development place economic at growth, and place the environmental factor or ecosystem at less considered position. The provision of marine and fishery resources very depend on the marine ecosystem. It means, it should be done conservation steps to protect ecosystem stability, including to ensure the fishing business not violate the ecosystem carrying capacity of the sea. Formation of one roof enforcement system that produce Task Force of Illegal Fishing Eradication formed by Presidential Regulation No 115 Year 2015[10].

Task force of Illegal Fishing Eradication or Task Force 115 with 5 (five) members, law enforcer institution in the fishery field, that is KKP, TNI AL, Waters Police, Bakamla, and Indonesian Republic Prosecutors' Office, and headed by Marine and Fishery Ministry as command. Based on Presidential Regulation of formation, the main task of the Task Force 115 is to develop and implement the law enforcement operation in effort to eradicate the illegal fishing in Indonesian sea effectively and efficiently, by optimizing the personnel use and operation tools owned by Task Force 115. 
As unit formed to make breakthrough in conducting illegal fishing enforcement, Task Force 115 conduct active coordination function among law enforcer by using legal multi discipline approach, or known as multidoor, then in 2017 SOP about action to sink illegal fishing foreign boat regulated in Ministerial Regulation of Marine and Fishery No. 37/PERMEN-KP/2017 about Standard Operational Procedure of law enforcement of the Task Force for illegal fishing boat eradication.

A. Subjective requirements and/ objective, that is: [9]

1. Subjective requirement, boat make maneuver which is danger and / or the boat captain / crew against violently, and /or

2. Objective requirements, consist of:

a. Cumulative requirement:

i. Boat with foreign flag with all foreign crew;

ii. Crime scene (Locus delicti) at the Fishery Management Area of The Republic of Indonesia (WPPNRI);

iii. Have no documents from the government of The Republic of Indonesia, and

iv. Conducted with prudent principle and based on the leader order.

b. Alternative requirements, that is:

i. Old boat supported with document and / or have no high economic value, and

ii. Boat not feasible to bring to the port that handle fishery with consideration: the boat easy to damage or dangerous, the boat pulling cost too high, or fishing boat contain disease or dangerous substances.

B. Before conducting burning or sinking can be taken action:

1. Save maximally all crew of the boat;

2. Inventory all equipment and tools in the boat by stating the condition in detail and completely.

3. Document visually well by using camera or audio video recorder,

4. The caught fishes burned/sunk taken partly for proofing needs,

5. Make official note of burning/sinking of fishing boat entered into sailor news by relevant institution.

Presidential Regulation No. 115 Year 2015 about task force of illegal fishing boat contain 4 section that not suitable with the statute principle, that is consideration, recall to, article 2 , article 3 , and article 6 . Related with the formation of Task force of Illegal Fishing, there are related regulation: Law No 45 Year 2009 about Fishery Law, Law No. 34 Year 2004 about Indonesian National Army, Law No. 3 Year 2002 about defense; Presidential Regulation No. 63 Year 2015 about Ministry of Marine and Fishery; and Presidential Regulation No. 178 Year 2015 about Marine Security Agency.

Article 6 letter b of Presidential Regulation, which regulates about general guidance for operational implementation, states the KKP Ministry is the only commander of the task force who has authority to implement the command and control for the task force element and each element should report about the their task to the commander of the task force. Then article 6 letter $\mathrm{c}$ that government that government can be given by Task Force Commander (KKP Minister) to the Daily Implementation Head (Staff Head of Navy) to be implemented by Joint Team. In this case, it can be seen overlapping of authorities. The completion needs of SOP, to be made more detail and integrated into each task in each unit of law enforcer in Indonesia waters. The existing SOP should be added procedures about marine environment pollution, sinking location selection, sinking procedure and standard cost for sinking so can be done as efficient as possible.

\section{CONCLUSION}

The marine quarantine should become part of existing SOP so can be made in more detail and integrated. Marine quarantine related with the marine environment prevention standard and determination for sinking location selection, so the environment can be preserved with efficient sinking cost. The SOP should contain about the sinking procedure for illegal fishing foreign boat, burned, exploded, or cut. With marine quarantine then SOP which is implemented become system that has legal certainty. Then the sinking sanction procedure should through fixed procedure in the form approval from district court to get legal certainty.

\section{REFERENCES}

[1] CNN Indonesia, "CNN Indonesia," 2016.

[2] P. R. of V. H. Directorate General Marine and Fishery Supervisory, "Performance Report of Violation Handling of 2016," 2017.

[3] Kompas, "Kompas."

[4] M. R. Inurhadi, "Illegal, Unreported, Unregulated Fishing (IUUF) in Indonesian Waters in Era of Joko Widodo Administration."

[5] A. E. and W. Jefrizal, "llegal Fishing Boat Sinking in Indonesia area in the Perspective of International Law."

[6] Y. Istanto, "Illegal fishing boat sinking as effort to enforce the fishery law in Indonesia (Study of Decision No 4/PID.SUSPRK/2014/PN-TPG District Court of Tanjung Pinang)," 2015.

[7] T. Jiahua, “The New Development of China's Maritime Security Strategy, Thought Based on the View of 21st-Century Maritime Silk Road," Proceeding Int. Coference Polit. Econ. Law-ICPEL, 2016.

[8] Q. Shen, "Analysis of Current Status and Causes of Maritime Accidents," Proceeding Int. Coference on, Econ. Manag. Law Educ., 2015.

[9] M. M. and Fisheries, Standard Operational Procedure of Law Enforcement of Illegal Fishing Eradication. Indoensia, 2017.

[10] President of Indonesia, Task Force of Illegal Fishing Eradication. Indonesia, 2015. 